\title{
Study on the Outward FDI in the USA of Chinese Enterprises
}

\author{
Shuangqin Liu, Zhi Li \\ Business School of Hohai University, Nanjing, China \\ Email: Isqcarol@163.com \\ Received 13 May 2015; accepted 11 July 2015; published 14 July 2015
}

\begin{abstract}
With the rapid economic development, China has sufficient foreign exchange reserves. Together with the appreciation in Chinese currency and other conditions, more and more Chinese enterprises invest overseas especially in the USA. Based on the statistics of the National Bureau of Statistics of the People's Republic of China, in 2012 and 2013, among the top 3 countries in which Chinese enterprises have invested, the USA ranked the second with US\$ 4047.85 million and the third with US\$ 3873.43 million respectively. Chinese enterprises' FDI in the USA has been mutually beneficial to both China and the USA. However, Chinese enterprises' FDI in the USA has encountered a variety of obstacles from the USA including American government's interfering with FDI by political methods, difficulty to enter into some industries, and America's protectionism. On the other hand, those Chinese enterprises also have some problems in their outward FDI in the USA such as unstable development trend of FDI, enterprises of small size with the privately-owned enterprises as the main body, and unfamiliarity with the related policies and laws. What countermeasures should Chinese enterprises adopt to deal with the obstacles or problems? This paper aims at analyzing the obstacles from the USA and the problems existing in those Chinese enterprises' FDI in the USA by means of SWOT method and puts forward some corresponding countermeasures for the Chinese enterprises to conduct their outward FDI in the USA more effectively. The conclusions can be used for reference by companies which plan to invest in the USA or other foreign countries.
\end{abstract}

\section{Keywords}

Outward FDI in the USA, Chinese Enterprises, Obstacles, Problems, Countermeasures

\section{Introduction}

With the economic globalization, more and more Chinese companies invest overseas. According to the statistics of the National Bureau of Statistics of the People's Republic of China in 2012 and 2013, among the top 3 countries in which Chinese enterprises have invested, the USA ranked the second (US\$ 4047.85 million) and the third (US\$ 3873.43 million) respectively. How is those Chinese companies' FDI developing in the USA now? Did the companies' FDI encounter any obstacles or problems in the USA? What countermeasures should they adopt so as to deal with the obstacles or problems? This paper discusses all these questions as well as draws 
some conclusions by means of SWOT analysis method. The conclusions can be used for reference by companies which plan to invest in the USA or other foreign countries.

\section{Literature Review}

Zhang Rui stated the basic features of China's FDI conducted in the USA, analyzed the factors driving and restricting China's FDI in the USA and put forward some suggestions on the restricting factors, for example, both China and USA should strengthen political mutual trust and understanding to facilitate the development of FDI in the USA [1].

Sun Jian, Yu Liang also mentioned the characteristics of China's FDI development in the USA, studied the obstacles to China's FDI in the USA and finally gave some suggestions [2].

Du Qiong, Wang Meng discussed the features, affecting factors and the development trend of the bilateral FDI between China and USA [3].

Peng Bo used a multiple linear regression method to analyze the factors affecting China's FDI in the USA and put forward some suggestions on China's expanding FDI in the USA [4].

Chen Qingmin analyzed the obstacles to China's FDI in the USA, introduced Japan's experience in its FDI in the USA, and finally put forward some methods for Chinese companies to solve the problems [5].

Zhang Han, Xiu Yuanyuan used a regression method to analyze the status quo, the features, and the existing problems of China's FDI in the USA, and in the meantime gave some suggestions on the problems [6].

Wang Honghong, Tian Zhen introduced Japan's and UK's experience in their FDI in the USA, and also put forward some suggestions for Chinese enterprises to invest in the USA [7].

Li Yuejie conducted a comparison study about the FDI in the USA made by Japan and China, pointed out the characteristics of the two countries' FDI in the USA respectively and put forward some suggestions for Chinese enterprises [8].

The above researches are conduced from a certain point of view. This paper, integrating with the relevant literature, adopts SWOT method to analyze the obstacles from the USA as well as the problems existing in those Chinese enterprises' FDI in the USA, and on the basis of the above analysis, puts forward some corresponding countermeasures for the Chinese enterprises.

\section{SWOT Analysis of China's outward FDI in the USA}

Based on the related researches on Chinese enterprises' outward FDI in the USA, SWOT method is adopted to analyze Chinese enterprises' outward FDI in the USA as shown in Figure 1.

\section{The Obstacles from the USA and the Problems Existing in Those Chinese Enterprises' FDI in the USA}

By means of SWOT analysis and integrating with the relevant researches, it can be found that the obstacles from the USA and the problems existing in those Chinese enterprises' FDI in the USA are as follows.

\subsection{The Obstacles from the USA}

1) American Government's Interfering with FDI by Political Methods

When China's enterprises plan to have mergers and acquisitions in the USA, they have to obtain American government's approval, i.e. the American government carries out the national security review as to China's enterprises. In many cases, enterprises especially those with Chinese background or with the background of Chinese government are treated in different ways from other enterprises in the USA. American government resists China's mergers and acquisitions with those American companies with critical technologies, in particular, is strongly against Chinese government's support in Chinese enterprises' mergers and acquisitions with those American companies with critical technologies. American government's political methods have restricted the normal development of Chinese enterprises' FDI in the USA.

2) Difficulty to Enter into Some Industries

Those Chinese enterprises that carry out mergers and acquisitions in the USA are competitive, especially competitive in high-tech industry. Unfortunately, according to American regulations, foreign enterprises are restricted to invest in the USA in these industries, including shipping, energy source, media, infrastructure, banking, etc., which results in more risks and uncertainties to the Chinese enterprises. In the high-tech industry, the 


\begin{tabular}{|c|c|c|}
\hline 胥 & $\begin{array}{c}\text { Strengths } \\
\text { 1. Domestic rapid economic development } \\
\text { 2. Sufficient foreign exchanges } \\
\text { 3. Appreciation in Chinese currency } \\
\text { 4. China's higher trade position } \\
\text { 5. China's carrying out the strategy of investing } \\
\text { overseas }\end{array}$ & $\begin{array}{c}\text { Weaknesses } \\
\text { 1. Increase in raw material cost } \\
\text { 2. Increase in labor cost } \\
\text { 3. Small size and weak competitiveness of } \\
\text { enterprises } \\
\text { 4. Lacking experience in overseas FDI }\end{array}$ \\
\hline 苞 & $\begin{array}{c}\text { Opportunities } \\
\text { 1. Further globalizing } \\
\text { 2. High level development of American economy and } \\
\text { technology } \\
\text { 3. American good infrastructure } \\
\text { 4. American free and stable policies and their stable } \\
\text { laws } \\
\text { 5. Local governments' favorable policies }\end{array}$ & $\begin{array}{l}\text { Threats } \\
\text { 1. American government's interfering by } \\
\text { political methods } \\
\text { 2. Lobbying of the interest groups concerned } \\
\text { to their government } \\
\text { 3. Complex law and policy environments of } \\
\text { investment } \\
\text { 4. Difficult industry access } \\
\text { 5. Other competitors in the USA }\end{array}$ \\
\hline
\end{tabular}

Figure 1. SWOT analysis of China's outward FDI in the USA.

USA has been giving high pressure to the Chinese enterprises. In addition, the American government worries about the fact that the Chinese enterprises will transfer technical equipment and production capacity after they merge and acquire American enterprises.

3) America's Protectionism

China's economy is developing rapidly. American trade deficit with China is increasing. When Chinese enterprises invest in the USA, they suffer not only the pressure from American government, but also the protectionism from the American industry. And the protectionism is becoming fiercer. Those Chinese enterprises that have invested in the USA have advantages in manufacturing, which results in pressure to the local American companies, therefore, American industry associations and trade unions make various kinds of lobbying to their government, and their government has to set some investment barriers to restrict some Chinese enterprises' investment there so as to protect their industrial interests as well as the social security.

\subsection{The Problems Existing in Those Chinese Enterprises' FDI in the USA}

1) Unstable Development Trend of FDI

In spite of the fact that more and more Chinese enterprises invest in the USA, the development trend of FDI in the USA is not stable. As per the National Bureau of Statistics of the People's Republic of China in 2011,2012 and 2013, the FDI conducted by Chinese enterprises in the USA were US\$ 1811.42 million, US\$ 4047.85 million and US\$ 3873.43 million respectively. Obviously, the development trend of FDI made by Chinese enterprises in the USA is not very stable.

2) Enterprises of Small Size and with the Privately-owned Enterprises as the Main Body

Most of the enterprises having invested in the USA are privately-owned enterprises, and they are characterized by small size and very limited competitiveness. Even there are a few large-sized enterprises with sufficient capitals and strong competitiveness, they are almost state-owned which are liable to encounter resistance in the USA.

3) Unreasonable Investment Methods with Greenfield Investment as the Main Body

China began to invest in the USA only about a decade ago. Prior to 2008, the major investment method is Greenfield investment. After that, there are more and more mergers and acquisitions, but the proportion of mergers and acquisitions is not large enough.

4) Unfamiliar with the Related Policies and Laws

American law systems are complete, complex and specific, thus it is hard for Chinese enterprises to understand those policies related to investment well during a short period of time. Chinese enterprises have much pressure at the early stage of their investment, their investment cost is high, and in the meantime, they also suffer various difficulties in their operation afterwards.

\section{Countermeasures}

\subsection{Reinforcing Communication, Public Relations and Propagation in the USA}

In the USA, the Chinese enterprises need to reinforce communication, public relations and propagation with 
American government, the local governments, the related industry associations and trade unions, the interest groups, etc. The Chinese enterprises may emphasize the advantages of investing in the USA such as providing job opportunities, increasing tax income to the American government to iron out its worry about Chinese economic development as well as about security. On the other hand, they can propagate to the American society, the industry associations, the trade unions, the interest groups, etc. that they invest in the USA without any political purpose to get their understanding, support and cooperation.

\subsection{Obtaining Support from the Chinese Government}

Those Chinese enterprises investing in the USA need capitals as well as guidance from Chinese government. Chinese government should not only provide support in capital and guidance to the state-owned enterprises but also to the privately-owned enterprises, because currently they still account for the most part of China's outward FDI in the USA. If the privately-owned enterprises can invest in the USA successfully, they can make a great contribution to China's outward FDI in the USA.

\subsection{Improving Governance Structures to Enlarge Investment Scope}

Most part of China's FDI in the USA is made by the privately-owned enterprises, which are not so competitive as multinational corporations. So they need to further reform in systems and gradually improve their governance structures with a view to increasing their competitiveness and thus enlarging their investment scope.

\subsection{Familiar with and Adaptive to the Investment Environment in the USA}

Before conducting FDI in the USA, Chinese enterprises should analyze and study the investment environment of the USA. They need to be familiar with and adaptive to the relevant investment environment including political environment, law environment, policy environment etc. as soon as possible. In the meantime they need to do risk evaluation about their mergers and acquisitions in order to minimize their investment risks.

\subsection{Choosing Investment Methods Flexibly}

Chinese enterprises should study and explore new investment methods in the USA. They should choose appropriate investment modes according to their own specific conditions, especially when they plan to do mergers and acquisitions. They should choose the industries in which they will invest very carefully. They should also take into consideration investing in the industries in which they can bring their comparative advantages into play so as to optimize their investment structure.

\subsection{Reinforcing Cooperation with the Local American Companies}

Chinese enterprises should have more and more cooperation with the local American companies, by which showing the American companies that they invest in the USA in order to grow with the local companies together and develop new markets together other than compete with them for market shares. By doing so the local American companies will understand them, support them and cooperate with them, thus reducing the lobbying of the related industry associations and trade unions to their governments.

\section{Conclusion}

SWOT method is applied to analyze Chinese enterprises' FDI in the USA. The analysis results indicate that on the one hand, the Chinese enterprises should cope with the various relations with the American parties concerned so that they can get understanding, support and cooperation from the American side, while on the other hand, they should analyze their own advantages and weaknesses so that they can make full use of their advantages to iron out their weaknesses. Moreover, they need to get supports from the Chinese government. If so, their outward FDI in the USA will be more effectively.

\section{References}

[1] Zhang, R. (2011) The Current Situation of Chinese Direct Investment in the USA and Suggestions for Its Further De- 
velopment. China Money, 6, 27-31.

[2] Sun, J. and Yu, L. (2013) Study on Obstacles to China's Outward FDI in the USA. Forecasting, 1, 1-6.

[3] Du, Q. and Wang, M. (2013) Features and Development Trend of the Bilateral FDI between China and USA. China Economic \& Trade Herald, 15, 26-28.

[4] Peng, B. (2013) An Empirical Analysis on the Influence Factors of China's Direct Investment in the USA. Technoeconomics \& Management Research, 6, 84-88.

[5] Chen, Q.M. (2013) China's FDI in the USA and Japan's Experience, Market Modernization, 27, 39-40.

[6] Zhang, H. and Xiu, Y.Y. (2013) Empirical Research on Choosing Mode of Chinese Enterprises' Investment to the USA. The Theory and Practice of Finance and Economics, 9, 55-58.

[7] Wang, H.H. and Tian, Z. (2013) Experience from UK and Japan for China's Direct Investment in the USA. Asia-Pacific Economic Review, 6, 60-65.

[8] Li, Y.J. (2013) Comparison between China's and Japan's FDI to the USA under the Impact of the Currency Appreciation. Journal of Jiangsu Radio \& Television University, 6, 81-85. 